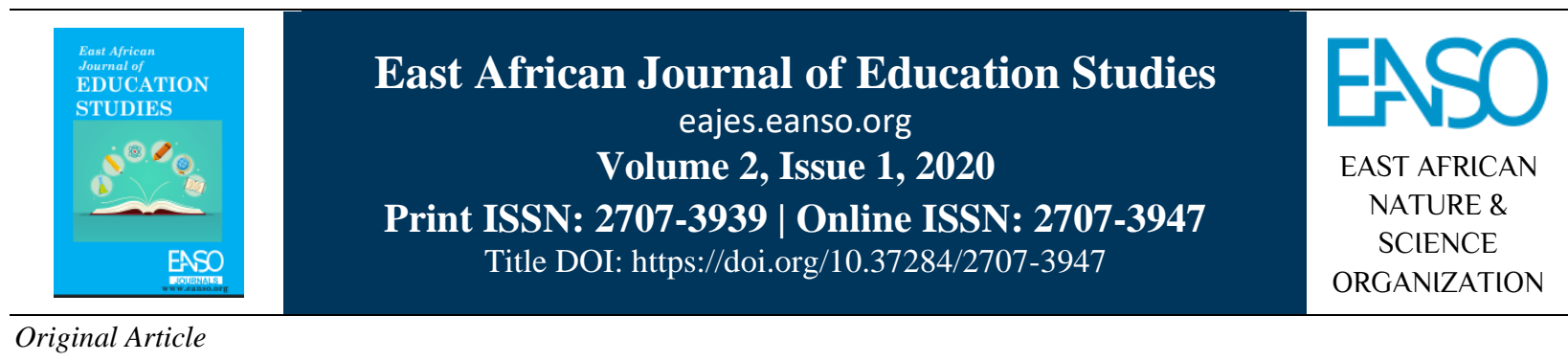

\title{
Modelling Academic Performance Using Attributes of Education Maturity with Multi-Level Composite Indicators: A Case of Wakiso District (Uganda) Primary Schools
}

\author{
Elly Ssebyatika ${ }^{1} \&$ Richard O. Awichi, $P h D^{2 *}$ \\ ${ }^{1}$ Uganda Martyrs University, P. O. Box 5498, Kampala, Uganda. \\ ${ }^{2}$ Department of Mathematics, Faculty of Science and Education, Busitema University, P. O. Box 236 Tororo, Uganda. \\ * Author for Correspondence Email: ichbinrao@gmail.com or rawichi@sci.busitema.ac.ug. \\ * ORCID: https://orcid.org/0000-0003-1753-7325
}

Article DOI: https://doi.org/10.37284/eajes.2.1.222

\section{Date Published: ABSTRACT}

13 October 2020 The major purpose of the study was to model the effect of education maturity on academic performance in primary schools in Wakiso district using multiKeywords: level composite indicators. Specifically, the study sought out to establish the

Education Maturity, Multi-Level Composite Indicators, Inspection, Academic Performance. extent to which supervision of teaching affects the academic performance of primary schools in Wakiso district; how teaching and learning resources affect the academic performance of primary schools in the district; how continuous school assessment affects the academic performance of primary schools in the district and how classroom environment affects the academic performance of primary schools in the district. The study employed a case study design together with methodological triangulation so as to minimize the challenges of using a single approach. The study used a census of primary schools. However, of the 350 schools, 218 provided all the required information on the study objectives. The main tools of data collection were document review and observation guide for the selected primary schools. The inferential analyses showed that at a $1 \%$ significance level, the use of resources and classroom environment significantly affected the academic performance of pupils in Wakiso district for the period under study. Secondly, teaching and learning resources significantly affected the academic performance of pupils in the district. Thirdly, at a 5\% level, assessment, recording and reporting significantly affected the academic performance of pupils in the district and lastly, supervision of teaching and learning significantly affected the academic performance of pupils. The study recommends that modelling academic performance using attributes of education maturity yields very significant information that helps greatly in making 
decisions on school performance and this should be encouraged and upscaled by the line ministry of education.

\begin{abstract}
APA CITATION
Ssebyatika, E., \& Awichi, R. (2020). Modelling Academic Performance Using Attributes of Education Maturity with MultiLevel Composite Indicators: A Case of Wakiso District (Uganda) Primary Schools. East African Journal of Education Studies, 2(1), 129-140. https://doi.org/10.37284/eajes.2.1.222.
\end{abstract}

\title{
CHICAGO CITATION
}

Ssebyatika, Elly, and Richard Awichi. 2020. "Modelling Academic Performance Using Attributes of Education Maturity with Multi-Level Composite Indicators: A Case of Wakiso District (Uganda) Primary Schools". East African Journal of Education Studies 2 (1), 129-140. https://doi.org/10.37284/eajes.2.1.222.

Ssebyatika, E. and Awichi, R. (2020) "Modelling Academic Performance Using Attributes of Education Maturity with MultiLevel Composite Indicators: A Case of Wakiso District (Uganda) Primary Schools", East African Journal of Education Studies, 2(1), pp. 129-140. doi: 10.37284/eajes.2.1.222.

\section{IEEE CITATION}

E. Ssebyatika, and R. Awichi, "Modelling Academic Performance Using Attributes of Education Maturity with Multi-Level Composite Indicators: A Case of Wakiso District (Uganda) Primary Schools", EAJES, vol. 2, no. 1, pp. 129-140, Oct. 2020.

\section{MLA CITATION}

Ssebyatika, Elly, and Richard Awichi. "Modelling Academic Performance Using Attributes of Education Maturity with MultiLevel Composite Indicators: A Case of Wakiso District (Uganda) Primary Schools". East African Journal of Education Studies, Vol. 2, no. 1, Oct. 2020, pp. 129-140, doi:10.37284/eajes.2.1.222.

\section{INTRODUCTION}

Despite efforts by the various stakeholders to improve academic performance through improved school inspection programs, the performance of primary schools has not improved as required. Further, there was limited academic evidence to support the claim that education maturity affects the academic performance of primary schools in Uganda. In various education systems, the school inspection process, also known as external evaluation, is carried out by either an independent agency or a semi-autonomous organ attached to the Ministry of Education (MOE) or by an organ within the MOE.

Scholars agree that the academic achievement of learners is a 'net result' of their cognitive and noncognitive attributes (Lee \& Stankov, 2016), as well as the sociocultural context in which the learning process takes place (Liem \& Tan, 2019). As used in the context of this paper, academic performance refers to the percentage of marks obtained by the pupils on each of the subjects at the end of an academic term or year.

Academic performance of learners is a key feature in education and is considered a centre around which the whole education system revolves. Narad and Abdullah (2016) opined that the academic performance of learners determines the success or failure of any academic institution. Abaidoo (2018) also argued that the academic performance of learners has a direct impact on the socio-economic development of a country. Similarly, Farooq et al. (2011) asserted that a learner's academic performance serves as a bedrock for knowledge acquisition and the development of skills.

Additionally, Farooq et al. (2011) emphasized that the topmost priority of all educators is the academic performance of learners. According to Narad and Abdullah (2016), academic performance is the knowledge gained which is assessed by marks awarded by a teacher and/or educational goals set by learners and teachers to be achieved over a specific period. They add that these goals are measured by using continuous assessment or examination results. Educational maturity is one aspect that education planners use a basis to formulate strategic policies for effective results in the education sector. In this study, the variable education maturity is proxied by results of multilevel composite indicators which include supervision of teaching, teaching and learning resources and continuous assessment as well as the classroom environment. 
According to Alkutich (2015), school inspection is one of the most challenging aspects of education; it represents an approach of accountability in teaching and learning. Moreover, it provides policy and decision-makers with accurate information about the current state of education in their respective institutions. Studies by Abaidoo (2018) and Alkutich (2015) have shown that countries with effective inspection systems have systematically laid down procedures for carrying out inspection activities including consulting previous inspection reports, decisions on which schools to inspect as well as the type and focus of inspection prior to inspection.

According to Bagaya et al., (2020), the education sector targets over the Uganda National Development Plan, NDP II period was to increase the completion rate of primary seven from $70.3 \%$ in $2013 / 14$ to $85 \%$ by $2019 / 20$; increase the transition rate to secondary from $73 \%$ in $2013 / 14$ to $83 \%$ by 2019/20; increase net secondary completion rate from about $36 \%$ in $2012 / 13$ to $50 \%$ by $2019 / 20$. All these targets are quantitative in nature, and not a single one is qualitative (focussing on academic performance of learners).

Attaining quality education is a step by step process that takes several years, if not decades to build and it is heavily influenced by forces including the government, school, teachers, pupils and the parents (Nakanwagi, 2016). The academic performance of Ugandan primary schools can be best measured using the results of the Uganda National Examinations Board (UNEB) resulting from the national primary leaving examinations (PLE). Using data from UNEB, the academic performance of the pupils in the primary level has been declining since the introduction of UPE owing to the increased number of pupils.

Wakiso district is one of the districts that perform best when it comes to PLE as the district has all requisites for performance improvement, including teachers and structures (Nakanwagi, 2016). However, the case of the academic performance of pupils in the Wakiso district is not significantly different from the performance at the national level. An analysis of UNEB metadata shows that amidst an increase in the number of learners in the first three grades, the number of pupils in the first four aggregates at PLE has also exhibited a declining trend over the period 2000 and 2018.

\section{LITERATURE REVIEW}

\section{Effect of Supervision of Teaching on Academic Performance}

Oyewole and Ethinola (2014) saw the supervision of teaching as an important instrument for providing a mechanism for teachers and supervisors to enhance their understanding of the teachinglearning process through collective inquiry with other professionals. According to Azure (2016), the purposes of supervision can be grouped under the following themes: improving instruction; fostering curriculum and staff development; encouraging human relations and motivation; and encouraging action research and supporting collaboration. Azure (2016) further notes that supervision of instruction is required to guide teachers to be able to combine relevant input for the enhancement of the teachinglearning process. According to Maimela \& Monyatsi (2016), supervision was initially described as inspection, which has the connotation of the direct control of teachers by school inspectors. The term supervision has gradually taken over inspection, but both terms are sometimes used together.

Supervisors had nearly unlimited power to establish criteria for effective instruction and to hire and fire teachers. Because there was no necessary agreement as to the importance or nature of pedagogical expertise, the quality and type of feedback to teachers were highly varied (Marzano et al., 2011). Effective supervision as explained by Gordon (2004) requires well-trained personnel with knowledge, interpersonal skills, and technical skills who are prepared to provide the necessary and appropriate guidance and support to the teaching staff.

Okendu (2012) noted that the instructional process and supervision helped a lot in improving the academic performance of learners. This is because supervision of instruction aims at enhancing teaching and learning through proper guidance and planning, and devising ways of improving teachers professionally and thereby helping them release their creative abilities so that through them the 
instructional process is improved and wellarticulated The importance of instructional supervision on the achievement of effective learning in today's educational system can consequently not be over-emphasized especially at the secondary school level which is perceived to be a vital step for career decisions.

\section{Teaching and Learning Resources on Academic Performance}

Children with special needs are not required to meet the classroom standards; rather the classroom meets the individual needs of all children. In Kenya, Yara and Omondi (2010) argue that school management and teachers should make efforts to identify and attend to learners with special learning needs, for instance, dietary needs especially pre-school. Oyugi and Nyaga (2010) note that teaching and learning resources include peripatetic services, support staff (sign language interpreters and Braille transcribers), community involvement, regular and special teachers among others. According to Kochung (2011), inadequate trained special needs education teachers and professionals are obstacles to the implementation of inclusive education.

Adequacy of teaching and learning resources (TLR) refers to satisfactory or acceptable quality and quantities of material resources, physical facilities and human resources. According to Ilomo and Mlavi (2016), the adequacy of instructional materials such as textbooks which is the main instruction material is the most cost-effective input affecting learner performance. In this context, adequate supply is usually assumed to be a minimum of one textbook per three learners, and at the primary level enough reading books so that every child has the opportunity to read at least one new book every week.

In Kenya, Mudulia (2012) stated that adequacy of TLR determines the efficiency of an educational system effective teaching and learning, textbook and resource materials are basic tools, their absence or inadequacy makes teachers handle subjects in an abstract manner, portraying it as dry and nonexciting. It is also important to have an appropriate personnel plan for adequate instructional materials and physical facilities to support the educational effort. To Orodho et al. (2013), the scarcity of textbooks, libraries and physical facilities constrain the educational system from responding more fully to new demands. In order to raise the quality of education, its efficiency and productivity, better teaching and learning materials (TLM), physical facilities and human resources are needed.

TLR comprises three components: human resources, material resources and physical facilities. Studies done in the past with regard to the availability of TLR in education reveal that TLR are not always available in schools. This inadequacy of TLR has been of serious concern to educators. According to Okeke and Okoye (2013), learning is a complex activity that involves the interplay of the motivation of learners, physical facilities, teaching resources, and skills of teaching and curriculum demands. In Uganda, Nannyonjo (2007) discovered a very strong positive significant relationship between instructional resources and academic performance. This assertion is supported by Zachariah (2011) who noted that schools endowed with more materials performed better than schools that are less endowed. Despite a plethora of studies, very few have been actually carried out to investigate the effect of TLR on academic performance using inferential statistics.

\section{Effect of Continuous Assessment on Academic Performance}

Assessment of learning is not a one-time movement; it is a progressing process. It includes the procedure of checking on, reflecting and modifying the learning techniques in an arranged and cautious way. When an assessment is carried out in the classroom in an ongoing or continual way by the teacher it is called continuous assessment (Kabambwe, 2010). In this process, Fenta (2012) states that observations are made from time to time to collect data to determine the level of learners' knowledge, understanding and performance. It is done by giving particular tasks to learners based on their previous achievement in the classroom. Teachers cautiously observe the activities of learners to decide about the level of their performance in class. It also helps them to find out what the learners have learned. Continuous assessment is part and parcel of the instructional process that has to be taken as a key tool in educational quality assurance endeavour (Huxham, Campbell \& Westwood, 2010). 
According to Zeleke (2013), the nature of continuous assessment in the context of international perspectives concerning teacher assessments is organized under the subtopics of continuous assessment and curriculum-based assessments. The scholar explains, in countries that have evidently designed national curriculum, continuing, influential assessment is typically based on aim and attached directly to the aims for the curriculum designed for all the learners (Kolawole \& Ala, 2014). National strategies for assessment may define what needs to be assessed and how it is to be done. For countries using this method, the main feature is that developing and applying assessment is mostly the duty of conventional schools and class teachers. This is according to the purpose of such an assessment for notifying decisions about next steps in an individual learner's learning trajectory (Zeleke, 2013).

To Kabambwe (2010), the purpose of continuous assessment is that the teacher can continuously assess learner's learning outcomes in all three domains- cognitive, affective, psychomotor, particularly with regard to knowledge and understanding, procedural knowledge (making comparisons and estimates performing calculations, applying formulas), problem-solving and other higher-order skills. Adewumi and Monisola (2013) noted that continuous assessment serves the purposes including providing information about the status and progress of each learner. It helps the teacher to know, plan redesign the teaching in accordance with the needs of the learners. It provides diagnostic information on the strengths and weaknesses of the learners' learning. It also provides feedback to the teachers for the modification of curriculum targets and textbooks.

\section{Effect of Classroom Environment on Academic Performance}

A classroom setting has two major components, namely, physical and human components. The physical component comprises all the physical objects present in the classroom, e.g. blackboard, furniture, lightings, projector, books, computers etc., whereas the human component comprises individuals, i.e., teachers and learners in the classroom. According to Alkharusi et al. (2012), classroom management is regarded as a core component of a powerful and fruitful instructional process; adding that effective and inspiring classroom management starts with efficient and effective lesson planning and assists an educator to instruct and learners to learn. Alkharusi et al. (2012) further note that learners achieve excellently in an encouraged and stimulating classroom environment and feel protected and contented. From the perspective of learners, powerful and fruitful classroom management gives them chances to mingle while picking up interesting and stimulating content. From an educator perspective, compelling classroom management includes precautionary, discipline and intriguing education (Suleman et al., 2011).

Classroom physical course of action gives learners powerful learning and advances effective instructional process. The provision of physical facilities may be ensured because these are useful in enhancing the general academic performance of the school (Suleman \& Hussain, 2014). Effective teaching and effective learners learning have been a central focus of the classroom environment in the current educational situation. Alkharusi et al. (2012) state that classroom needs proper facilities that contribute to teaching and learning. In this situation, learners sit on the ground under the sky or under the shady trees and teachers are unable to maintain the learning environment. So, the achievement of the learners remains low and disruptive behaviour is maximized. From the scholars' assertions, the physical environment alludes to the room's physical qualities and characteristics.

To Murugan and Rajoo (2013), the physical environment of the classroom is a mixture of various items, i.e., temperature, lighting, size of the room, ventilation, walls, floor, seats, mats, whiteboards, computers and so on. Teachers and learners are viewed as the primary components of the classroom condition. The scholars added that stimulating the physical environment possesses a critical constructive outcome on the productivity of any association and goes about as a catalyst to give a clear approach to accomplish the organizational prearranged targets. But regrettably, in most of our classrooms, physical condition is not helpful for a better instructional process causing learners' exhaustion and disappointment (Suleman \& 
Hussain, 2014). The physical environment is planned to discourage the learning procedure in spite of the fact that researchers have explored a close relationship between the physical condition and the work an individual performs.

Murugan and Rajoo (2013) explain that positive classroom learning situations are ones that boost learning for all learning and cultivate their improvement as all-encompassing creatures by considering scholarly, enthusiastic, social and physical development. They add that a positive learning environment is thoughtful and responsive. It is created and balanced after some time with reason and concentration on the wanted result of guaranteeing that all learners have entry to worldclass instruction.

\section{RESEARCH METHODOLOGY}

A soft copy of the national academic performance in Primary Level Examinations of the primary schools in the district was received from UNEB with data for the period of the study. A tool was also designed to evaluate those schools for the four themes and sub themes selected for this study. The tool captured all the aspects of the study themes, namely: Use of Resources and Classroom Environment; Teaching and Learning Process; Assessment of Records and Reporting and Supervision of the Teaching-Learning Process.
Several subthemes were also included in the tool. This tool was then administered to the respondents in order to obtain the data.

In order to gain more complete and comprehensive insights, we used the mixed methods approach where both qualitative and quantitative techniques were employed. Quantitative methods were used to generate the magnitude to which the study variables are related while qualitative methods were used to generate a human understanding of the relationship between the variables. We used both the case study research and correlational designs. The following regression model was used to establish the effects of combined attributes of education maturity on academic performance:

PERF $=\alpha+\beta($ CA $)+\gamma($ TLR $)+\delta($ CLASS $)+\theta($ TS $)+\varepsilon$

where; $\mathrm{PERF}=$ Performance, $\mathrm{CA}=$ Continuous Assessment, TLR $=$ Teaching and Learning Resources, CLASS $=$ Classroom environment, $\mathrm{TS}=$ Teacher Supervision, $\alpha, \beta, \gamma, \delta, \theta$ are model coefficients and $\varepsilon$ is the error term.

\section{RESULTS AND DISCUSSIONS}

\section{Analysis of Academic Performance}

Figure 1 presents an academic performance in terms of grades by gender as portrayed graphically.

\section{Figure 1: Descriptive Analysis of Academic Performance by Gender}

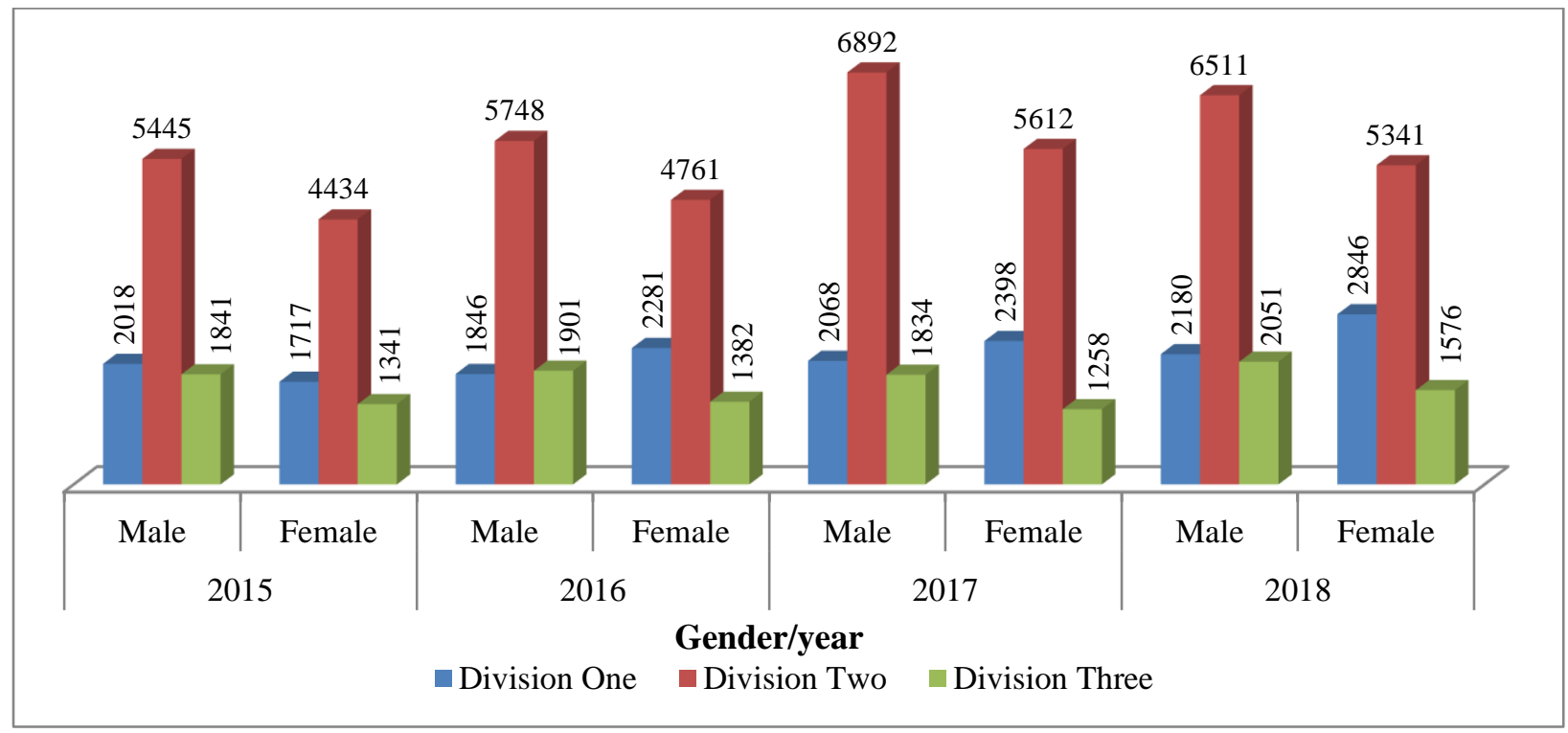




\section{Performance by Location and Ownership}

From Figure 1, there is a general notion that on average, the number of pupils in each grade has been increasing over the years. However, such descriptive analyses may indicate an overall improvement in academic performance but hardly shows any quality in the improvement of the performance over the years.
Table 1 indicates that there were performance differences by school ownership and location, albeit descriptively. The results indicate that more pupils $(75.8 \%)$ of those that had obtained first grades were from the urban primary schools while the distribution changed for the second and third divisions. This was attributed to the availability of teaching and learning materials but most especially electricity and serious prep studies in these schools.

Table 1: Performance by Location and Ownership

\begin{tabular}{llllllll}
\hline & & \multicolumn{2}{c}{ Division one } & \multicolumn{2}{c}{ Division two } & \multicolumn{2}{c}{ Division three } \\
\cline { 3 - 8 } & & Freq. & \% & Freq. & \% & Freq. & \% \\
\hline \multirow{3}{*}{ LOCATION } & Rural & 4199 & 24.2 & 28930 & 64.7 & 9212 & 78.1 \\
& Urban & 13155 & 75.8 & 15814 & 35.3 & 2590 & 21.9 \\
& Total & 17354 & 100 & 44744 & 100 & 11802 & 100 \\
\hline \multirow{3}{*}{ OWNERSHIP } & Private & 10986 & 63.3 & 31322 & 70 & 2850 & 24.2 \\
& Public & 6368 & 36.7 & 13422 & 30 & 8952 & 75.8 \\
& Total & 17354 & 100 & 44744 & 100 & 11802 & 100 \\
\hline
\end{tabular}

The results indicate that more pupils $(63.3 \%$ and $70 \%$ ) of those that had obtained first and second grades respectively were from the private primary schools while the distribution changed for the pupils that had passed in the third division. This was attributed to the fact that the private schools place a lot of emphasis on the value for money and client (parent) satisfaction through quality enforcement as compared to the quantity and inclusive education emphasized by the public primary schools. This, however, does not provide a scientific conclusion as to whether there exist differences in school academic performance by location and ownership.

\section{The Effect of Education Maturity on Performance}

In a bid to establish the relationship between the study variables, a correlation analysis was made at $1 \%$ significance level. Table 2 presents a summary of the correlation coefficients showing the relationships between the study variables.

Table 2: The relationship between education maturity indicators and performance

\begin{tabular}{lllllll}
\hline & & PERFORM & TSUPERV & LEARNRE & CLASSENV & CONTIASS \\
\hline PERFORM & Pearson Correlation & 1 & $.609^{* *}$ & $.502^{* *}$ & $.474^{* *}$ & $.171^{*}$ \\
& Sig. (2-tailed) & & .000 & .000 & .000 & .012 \\
& $\mathrm{~N}$ & 218 & 218 & 218 & 218 & 218 \\
\hline \multirow{2}{*}{ TSUPERV } & Pearson Correlation & $.609^{* *}$ & 1 & $.586^{* *}$ & $.842^{* *}$ & $.422^{* *}$ \\
& Sig. (2-tailed) & .000 & & .000 & .000 & .000 \\
& $\mathrm{~N}$ & 218 & 218 & 218 & 218 & 218 \\
\hline LEARNRE & Pearson Correlation & $.502^{* *}$ & $.586^{* *}$ & 1 & $.251^{* *}$ & $.520^{* *}$ \\
& Sig. (2-tailed) & .000 & .000 & & .000 & .000 \\
& $\mathrm{~N}$ & 218 & 218 & 218 & 218 & 218 \\
\hline CLASSENV & Pearson Correlation & $.474^{* *}$ & $.842^{* *}$ & $.251^{* *}$ & 1 & .097 \\
& Sig. (2-tailed) & .000 & .000 & .000 & & .152 \\
& $\mathrm{~N}$ & 218 & 218 & 218 & 218 & 218 \\
\hline CONTIASS & Pearson Correlation & $.171^{*}$ & $.422^{* *}$ & $.520^{* *}$ & .097 & 1 \\
& Sig. (2-tailed) & .012 & .000 & .000 & .152 & 1
\end{tabular}




\begin{tabular}{|c|c|c|c|c|c|}
\hline & PERFORM & TSUPERV & LEARNRE & CLASSENV & CONTIASS \\
\hline $\mathrm{N}$ & 218 & 218 & 218 & 218 & 218 \\
\hline
\end{tabular}

PERF = Academic performance, TSUPERV = Supervision of teaching and learning, LEARNRE = Availability of teaching and learning Resources, CONTIASS = Assessment, recording and Reporting, CLASSENV= Use of resources and Classroom environment and LEARNRE= Availability of teaching and learning Resources.

From Table 2, the statistics (Pearson Correlation $=$ $.609 * *, p=.000)$ imply that at a $1 \%$ significance level, there is a significant positive correlation between academic performance and teaching and learning supervision in the district. We thus reject the null hypothesis that: Supervision of teaching does not affect the academic performance of selected primary schools in the district. The significance of supervising teaching and learning is explained by the fact that it helps the teacher and learners get organized while controlling emotions, behaviour, enhancing teacher-learner interaction and improving feedback mechanisms for improved performance. According to Oyewole and Ethinola (2014), supervision of teaching and learning is important for matters of improving interaction, feedback and performance implying that the current study is an addition to the existing body of knowledge.

Similarly, for the other variables; (Pearson Correlation $=.502 * *, p=.000$, for LEARNRE) we reject the null hypothesis: the availability of teaching and learning resources does not significantly affect the academic performance of primary schools in the district. We thus conclude that availability of teaching and learning resources positively influence the academic performance of pupils in the district. Orodho et al., (2013) established that availability of teaching and learning resources significantly affected academic performance through improving the learner's ability to seek more knowledge at free will. Further, the statistics (Pearson Correlation $=.474^{*} *, \mathrm{p}=$ .000) imply that at a $1 \%$ significance level, there is a significant moderate and positive correlation between academic performance and use of resources \& classroom environment in selected primary schools in the district. Regarding the effect of the classroom environment, the study results are consistent with Suleman \& Hussain (2014) who stated that a positive classroom environment helps improve attention, reduces anxiety, and supports the emotional and behavioural regulation of students. We thus reject the hypothesis that the use of the classroom environment does not significantly affect the academic performance of primary schools in the district.

Lastly, the statistics (Pearson Correlation $=.171^{*}$, $\mathrm{p}=.000$ ) imply that at a 5\% significance level, there is a positive correlation between academic performance and continuous assessment in selected primary schools in the district. This is consistent with Torres-Guijarro \& Bengoechea, 2017 who posited that continuous assessment provides dayto-day feedback about the learning and teaching process. Assessment can reinforce the efficacy of teaching and learning. It also encourages the understanding of teaching as a formative process that evolves with feedback and input from students. This implies that they established that there were significant relationships between the variables under the respective studies and hence this study is an addition to the existing body of knowledge.

\section{Regression Analysis of the Effect of Education Maturity Indicators on Performance}

The multiple linear regression model of the effects of the attributes of education maturity on academic performance are presented in Table 3 and Table 4. 
East African Journal of Education Studies, Volume 2, Issue 1, 2020

Article DOI: https://doi.org/10.37284/eajes.2.1.222

Table 3: Model Summary: The effects of education maturity indicators

\begin{tabular}{|c|c|c|c|c|c|c|c|c|c|}
\hline \multirow[t]{2}{*}{ Model } & \multirow[t]{2}{*}{$\mathbf{R}$} & \multirow{2}{*}{$\begin{array}{l}\text { R } \\
\text { Square }\end{array}$} & \multirow{2}{*}{$\begin{array}{l}\text { Adjusted R } \\
\text { Square }\end{array}$} & \multirow{2}{*}{$\begin{array}{l}\text { Std. Error of } \\
\text { the Estimate }\end{array}$} & \multicolumn{5}{|c|}{ Change Statistics } \\
\hline & & & & & $\begin{array}{l}\text { R Square } \\
\text { Change }\end{array}$ & $\begin{array}{l}\text { F } \\
\text { Change }\end{array}$ & df1 & df2 & $\begin{array}{l}\text { Sig. I } \\
\text { Change }\end{array}$ \\
\hline 1 & $.683^{\mathrm{a}}$ & .467 & .463 & .27490 & .467 & 19.125 & 4 & 213 & .000 \\
\hline
\end{tabular}

In Table 3, a figure of 0.683 indicates that there is a high positive relationship between the stated education maturity indicators and the academic performance of primary schools in the district. The results in Table 3 further indicate that $46.3 \%$ of the changes in the academic performance of the selected primary schools in the district are explained by changes in the four stated education maturity indicators combined. The Sig. F Change value of .000 indicates that the model was correctly specified and that the effect of the four attributes on academic performance is significant at a $1 \%$ significance level.

Table 4: Coefficients: The effects of education maturity indicators

\begin{tabular}{|c|c|c|c|c|c|c|}
\hline \multirow{2}{*}{\multicolumn{2}{|c|}{ Model }} & \multicolumn{2}{|c|}{ Unstandardized Coefficients } & \multirow{2}{*}{$\begin{array}{l}\text { Standardized Coefficients } \\
\text { Beta }\end{array}$} & \multirow[t]{2}{*}{$\mathbf{t}$} & \multirow[t]{2}{*}{ Sig. } \\
\hline & & B & Std. Error & & & \\
\hline \multirow[t]{5}{*}{1} & (Constant) & 1.864 & .234 & & 7.980 & .000 \\
\hline & TSUPERV & .638 & .044 & .609 & 6.617 & .000 \\
\hline & LEARNRE & .561 & .038 & .502 & 4.631 & .000 \\
\hline & CONTIASS & .194 & .042 & .171 & 1.914 & .012 \\
\hline & CLASSENV & .482 & .040 & .474 & 3.731 & .000 \\
\hline \multicolumn{7}{|c|}{ a. Dependent Variable: PERFORM } \\
\hline
\end{tabular}

$\mathrm{PERF}=\mathbf{1 . 8 6 4}+\mathbf{0 . 6 3 8}$ TSUPERV $+\mathbf{0 . 5 6 1}$ LEARNRE $+\mathbf{0 . 1 9 4 C O N T I A S S ~}+\mathbf{0 . 4 8 2}$ CLASSENV

The results in Table 4 indicate that at a $1 \%$ significance level, a unit change in school inspection ratings about supervision of teaching and learning improves academic performance by $63.8 \%$. The $t$ value $>2$ indicates that for the stated number of observations, the effect of supervision of teaching and learning on the academic performance of these primary schools is significant. Secondly, at a $1 \%$ significance level, a unit change in school inspection ratings about availability and use of teaching and learning resources improves academic performance by $56.1 \%$. The $\mathrm{t}$ value $>2$ indicates that for the stated number of observations, the effect of availability and use of teaching and learning resources on the academic performance of these primary schools is significant. Further, at a $1 \%$ significance level, a unit change in school inspection ratings about the classroom environment improves academic performance by $48.2 \%$. The $\mathrm{t}$ value $>2$ indicates that for the stated number of observations, the effect of the classroom environment on the academic performance of these primary schools is significant. Lastly, at a $1 \%$ significance level, a unit change in school inspection ratings about continuous assessment improves academic performance by $19.4 \%$. The $\mathrm{t}$ value $<2$ indicates that for the stated number of observations, the effect of continuous assessment on the academic performance of these primary schools is insignificant at a $1 \%$ significance level.

\section{CONCLUSIONS AND RECOMMENDATIONS}

Table 2 and 4 bring out the importance of constant inspection in primary schools in Wakiso district for better academic performance by the learners. It is particularly significant that the supervisory roles of the school inspectors from the district and from the school administration be maintained and strengthened to improve on the academic achievements of both the schools and the district at the national level. It is also important to note that without putting in place any of the attributes of 
performance as investigated here, there would be only two (2) learners achieving desirable grades. This is evidenced by the regression model used when all study variables are put to zero. The coefficients of the variables give a relative measure of their importance in the relationship between the performance and the education maturity in the district.

On further inquiry, we noticed the need to focus more closely on the disadvantaged group of learners, improved record-keeping of continuous assessment results and more involvement of other relevant stakeholders like the School Management Committee and the Board of Governors in the affairs of the schools. We thus recommend to the schools and the district to focus on the above issues.

The authors are grateful to the anonymous reviewers whose comments improved the paper.

\section{REFERENCES}

Abaidoo, A. (2018). Factors contributing to the academic performance of students in a Junior High School. Munich: GRIN Verlag.

Adewumi, A. F., \& Monisola, K. A. (2013). Continuous Assessment, Mock Results and Gender as Predictors of Academic Performance of Chemistry Students in WASSCE and NECO Examinations in Ekiti State. International Education Studies, 6(7), 1-8.

Alkharusi, H., Aldhafri, S., Alnabhani, H., \& Alkalbani, M. (2012). Educational Assessment Attitudes, Competence, Knowledge, and Practices: An Exploratory Study of Muscat Teachers in the Sultanate of Oman. Journal of Education and Learning, 1(2), 217-232.

Alkutich, M. (2015). Examining the Impact of School Inspection on Teaching and Learning; Dubai Private Schools as a Case Study. Doctoral dissertation. The British University in Dubai (BUiD).

Azure, J. (2016). Students' perspective of effective supervision of the graduate programme in Ghana. American Journal of Educational Research, 4(2), 163-169.
Bagaya, J., Ezati, B. A., Wafula, W. S., \& Rasmussen, P. D. (2020). School Inspection Practices-Evidence from Secondary Schools in Western Uganda. Journal of Education and Training, 7(1), 56-76.

Farooq, M. S., Chaudhry, A. H., Shafiq, M., \& Berhanu, G. (2011). Factors affecting students' quality of academic performance: a case of secondary school level. Journal of quality and technology management, 7(2), 1-14.

Fenta, B. (2012). The Effects of Implementation of Continuous Assessment in Practical and Theoretical Classes of Sport Science Students in Debre Markos And Baher Dar Universities. MSc Thesis. Addis Ababa University.

Gordon, P. (2004). Numerical cognition without words: $\quad$ Evidence from Amazonia. Science, 306(5695), 496-499.

Huxham, M., Campbell, F., \& Westwood, J. (2012). Oral versus written assessments: A test of student performance and attitudes. Assessment \& Evaluation in Higher Education, 37(1), 125136.

Ilomo, O., \& Mlavi, B. (2016). The Availability of Teaching and Learning Facilities and Their Effects on Academic Performance in Ward Secondary Schools in MuhezaTanzania. International Journal of Education and Research, 4(6), 571-581.

Kapambwe, W. M. (2010). The implementation of school-based continuous assessment (CA) in Zambia. Educational Research and Reviews, 5(3), 099-107.

Kochung, E. J. (2011). Role of Higher Education in Promoting Inclusive Education: Kenyan Perspective. Journal of Emerging Trends in Educational Research and Policy Studies, 2(3),144-149.

Kolawole, E. B. and Ala, E. A. O. (2014). Effect of continuous assessment and gender on students' academic performance in mathematics in some selected states in the southwest Nigeria. Education Research Journal, 4(1), 1-6. 
Lee, J. \& Stankov, L. (2016). Non-Cognitive Influences on Academic Achievement. In: Khine M. S. \& Areepattamannil, S. (eds), Noncognitive Skills and Factors in Educational Attainment. Contemporary Approaches to Research in Learning Innovations. Rotterdam: Sense Publishers.

Liem, G. A. D., \& Tan, S. H. (Eds.). (2019). Asian education miracles: In search of sociocultural and psychological explanations. New York: Routledge.

Maimela, M. M., \& Monyatsi, P. P. (2016). Strategies for Improving the Academic Performance of Students in Botswana Primary Schools. World Journal of Educational Research, 3(1), 157-181.

Marzano, C., Ferrara, M., Mauro, F., Moroni, F., Gorgoni, M., Tempesta, D., ... \& De Gennaro, L. (2011). Recalling and forgetting dreams: theta and alpha oscillations during sleep predict subsequent dream recall. Journal of Neuroscience, 31(18), 6674-6683.

Mudulia, A. M. (2012). The relationship between availability of teaching/learning resources and performance in secondary school science subjects in Eldoret Municipality, Kenya. Journal of Emerging Trends in Educational Research and Policy Studies, 3(4), 530-536.

Murugan, A., \& Rajoo, L. (2013). Students' perceptions of mathematics classroom environment and mathematics achievement: A study in Sipitang, Sabah, Malaysia. In International Conference on Social Science Research, Penang, Malaysia.

Nakanwagi, R. M. (2016). School Culture and Students' Academic Performance in Private Secondary Schools in Wakiso District, Uganda. MSc Thesis. Uganda Management Institute.

Nannyonjo, N. (2007). Education Inputs in Uganda An Analysis of Factors Influencing Learning Achievement in Grade Six. World Bank Working Paper No. 98. Washington, DC: The World Bank.
Narad, A., \& Abdullah, B. (2016). Academic performance of senior secondary school students: Influence of parental encouragement and school environment. Rupkatha Journal on Interdisciplinary Studies in Humanities Special Issue, 3(2), 12-19.

Okeke, S. O., \& Okoye, N. E. (2013). Effective resource utilization: A better approach to teaching and learning of Physics. Academic Journal of Interdisciplinary Studies, 2(6), 3535.

Okendu, J. N. (2012). The influence of instructional process and supervision on academic performance of secondary school students of Rivers State, Nigeria. Academic Research International, 3(1), 332.

Orodho, J. A., Waweru, P. N., Ndichu, M., \& Nthinguri, R. (2013). Basic education in Kenya: Focus on strategies applied to cope with school-based challenges inhibiting effective implementation of curriculum. International Journal of Education and Research, 1(11), 120.

Oyewole, B. K., \& Ehinola, G. B. (2014). Relevance of instructional supervision in the achievement of effective learning in Nigerian secondary schools. Global Journal of Commerce and Management Perspective, 3(3), 88-92.

Oyugi, N. L., \& Nyaga, M. M. (2010). Introduction to contemporary issues affecting education. Nairobi, Kenya: Institute of Special Needs.

Suleman, Q., \& Hussain, I. (2014). Effects of classroom physical environment on the academic achievement scores of secondary school students in Kohat division, Pakistan. International Journal of Learning \& Development, 4(1), 71-82.

Suleman, Q., Aslam, H. D., Javed, T., \& Hussain, I. (2011). Barriers to the successful integration of educational technology in teaching-learning process at secondary school level in Khyber Pakhtunkhwa, Pakistan. International Journal of Research in IT \& Management, 1(8), 97-119. 
Torres-Guijarro, S., \& Bengoechea, M. (2017). Gender differential in self-assessment: a fact neglected in higher education peer and selfassessment techniques. Higher Education Research \& Development, 36(5), 1072-1084.

Yara, P. O. \& Otieno, K. O. (2010). Teaching/Learning Resources and Academic Performance in Mathematics in Secondary Schools in Bondo District of Kenya. Asian Social Science, 6(12), 126-132.

Zachariah, K. (2011). Adequacy and the Extent to which Teaching and Learning Resources for Mathematics are Available and Used for Achievement in the Subject in Secondary School in Kenya. American International Journal of contemporary research, 1(3), 1-16.

Zeleke, A. S. (2013). A comparative study on the practice of continuous assessment between Addis Ababa and Unity Universities. Educational Research and Reviews, 8(16), 1461-1469. 